\title{
IMPLEMENTASI ALGORITMA MONTE CARLO TREE SEARCH PADA PERMAINAN 2048 BERBASIS WEB
}

\author{
Alvin Kennedy ${ }^{1}$, Nur Fanny Savira ${ }^{2}$, Stefanus Andree Gunawan ${ }^{3}$, Lukman Hakim ${ }^{4}$ \\ Mahasiswa Universitas Bunda Mulia ${ }^{1}$, Dosen Universitas Bunda Mulia ${ }^{2,3,4}$ \\ Jalan Lodan Raya, RT.12/RW.2, Ancol, Kec. Pademangan, Kota Jakarta Utara, Daerah \\ Khusus Ibukota Jakarta \\ Sur-el : alvinkennedy45@gmail.com ${ }^{1}$, savirafanny@gmail.com², \\ stefanusandreegunawan@gmail.com ${ }^{3}$, lhakim@ @undamulia.ac.id ${ }^{4}$
}

\begin{abstract}
Artificial Intelligence is a new inovation in modern computer science that has been use in playing game. Game is very interested by many people, there is someone who make artificial intelligence to play a puzzle game that is 2048 that can be played automatically by computer using Monte Carlo Tree Search Algorithm through web-browser. Monte Carlo Tree Search is computation algorithm that using random sample. The website was design using flowchart and UML also made by using JavaScript for UX with the help of HTML for UI that can be played by AI with value runs input by user and doing test for comparing the difference result between each value runs by testing 5 times. Monte Carlo Tree Search Algorithm can be applied in playing game 2048.
\end{abstract}

Keywords: AI, Monte Carlo Tree Search, 2048, Game, Artificial Intelligence.

\begin{abstract}
Abstrak : Kecerdasan Buatan adalah sebuah inovasi baru dalam ilmu pengetahuan komputer modern yang digunakan untuk bermain game. Game sangat diminati oleh banyak orang, ada juga seseorang yang membuat kecerdasan buatan untuk memainkan game puzzle yaitu 2048 yang dapat dimainkan secara otomatis oleh komputer dengan algoritma Monte Carlo Tree Search melalui web. Monte Carlo Tree Search merupakan algoritma komputasi yang menggunakan sampel acak. Website yang dirancang menggunakan flowchart dan UML serta dibuat menggunakan JavaScript sebagai UX dengan bantuan HTML sebagai UI yang dapat dimainkan oleh AI dengan nilai runsnya dimasukkan oleh user dan melakukan pengujian untuk membandingkan hasil perbedaan antar setiap nilai runs dengan pengujian sebanyak 5 kali. Algoritma Monte Carlo Tree Search dapat diterapkan dalam permainan game 2048.
\end{abstract}

Kata kunci: AI, Monte Carlo Tree Search, 2048, Game, Kecerdasan Buatan.

\section{PENDAHULUAN}

Kecerdasan buatan (Artificial Intelligence) merupakan suatu inovasi baru dalam ilmu pengetahuan. Adanya kecerdasan buatan dimulai sejak munculnya komputer modern pada tahun 1940 dan tahun 1950 [1]. AI merupakan alat atau komputer yang dapat melakukan tugas yang dilakukan oleh manusia, oleh karena itu $A I$ juga dapat dimanfaatkan dalam kegiatan bermain game [2].
Game saat ini sangat diminati oleh sebagian besar orang karena gameplay yang menarik. Terkadang, ada juga yang membuat kecerdasan buatan untuk memainkan suatu game. Kecerdasan buatan tersebut dibuat dengan tujuan agar game dapat diselesaikan secara otomatis / dimainkan oleh komputer. Penerapan kecerdasan buatan tersebut akan diterapkan pada game 2048, dimana komputer akan menyelesaikan game dengan kecerdasan yang telah diprogram yaitu Monte Carlo. 
Monte Carlo merupakan algoritma komputasi yang dapat menggunakan sampel acak dalam menyelesaikan masalah. Monte Carlo dapat digunakan untuk menyelesaikan masalah pada beberapa bidang seperti fisika, game, matematika, dan bidang lainnya [3]. Monte Carlo Tree Search merupakan teknik pencarian $A I$ yang digunakan secara luas, MCTS bisa dengan cepat menemukan langkah yang bagus dalam proses mengambil keputusan sekuensial yang besar dan kompleks dengan mengkombinasikan search tree tradisional dengan evaluasi node berdasarkan simulasi stokastik [4].

\section{METODOLOGI PENELITIAN}

Metode Pengembangan sistem yang penulis gunakan pada penelitian ini yaitu metode extreme programing.

\subsection{Game}

Game adalah suatu sistem dimana pemain mengambil keputusan melalui objek yang dikendalikan didalam permainan yang memiliki satu atau banyak objektif. Ada beberapa jenis permainan yang sudah beredar saat ini yaitu: Role-Playing Game, First-Person Shooter, Puzzle Game, Adventure Game, Racing Game [5].

\section{$2.2 \quad$ Game 2048}

Game 2048 dimainkan pada kotak berukuran $4 \times 4$. Tujuan dari game 2048 adalah untuk mencapai nilai 2048 dengan memindahkan dan menyatukan tiles yang terdapat pada board $4 \times 4.2$ tiles secara acak berisi angka 2 atau 4 . Pemain dapat menggerakkan angka tersebut (keatas, kebawah, kekanan, dan kekiri). Ketika 2 tiles dengan angka yang sama bertabrakan, maka tiles tersebut akan menambahkan nilainya dan nilai tersebut adalah skor pemain [6].

\section{$2.3 \quad A I$}

$A I$ merupakan sains yang digunakan untuk mengimitasi kepintaran mahkluk hidup untuk diterapkan kepada mesin dengan tujuan pemecahan masalah. $A I$ memiliki beberapa metode yang dapat digunakan diantaranya Fuzzy Logic, Evolutionary Computing, Machine Learning, dalam penelitian ini penulis menggunakan metode Monte Carlo Tree Search [7].

\subsection{Monte Carlo Tree Search}

Monte Carlo Tree Search menggunakan Monte Carlo rollouts untuk mengestimasikan isi dari setiap bagian dari search tree. Semakin banyak simulasi yang dilakukan, search tree bertumbuh besar maka isi yang hasilkan lebih relevan [8]. Monte Carlo Tree Search adalah metode pencarian yang mengkombinasikan ketepatan pencarian tree dengan keumuman sampling acak [9].

\subsection{JavaScript}

JavaScript merupakan Bahasa pemrograman yang digunakan untuk menyempurnakan tampilan sistem web-based application yang dikembangkan, berupa sekumpulan script yang berjalan pada dokumen HTML [10]. 


\section{HASIL DAN PEMBAHASAN}

Cara kerja sistem yang digambarkan pada flowchart pada gambar 1. adalah user menjalankan program setelah itu user memasukkan input berupa suatu angka, lalu program akan idle jika user tidak menekan tombol run, jika user menekan tombol run maka sistem akan menghasilkan move secara otomatis. Jika belum kalah maka akan dilakukan move sampai kondisi lose adalah true, dan program akan selesai.

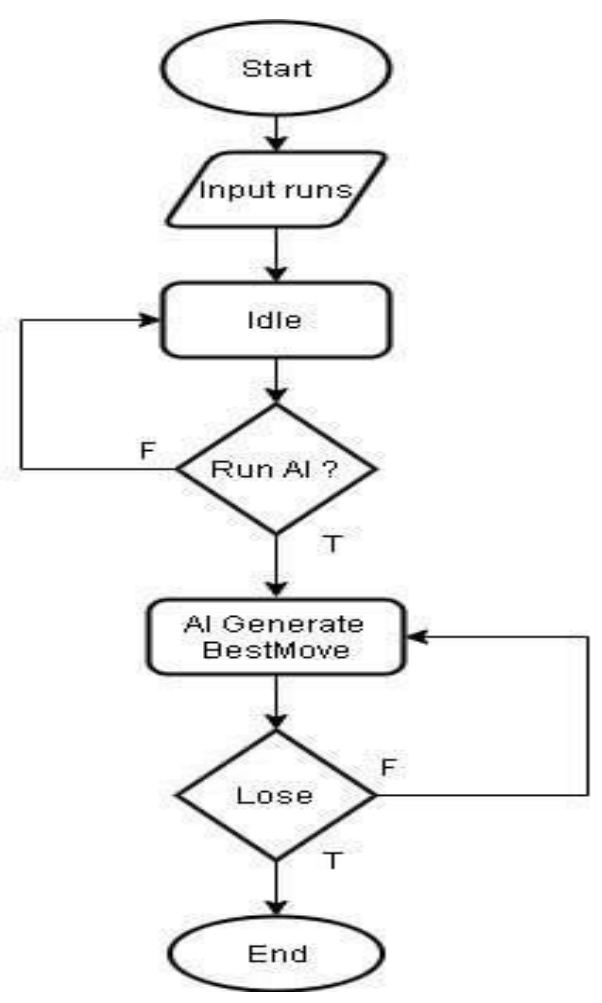

Gambar 1. Flowchart Program

Perancangan sistem yang dirancang penulis bertujuan untuk menggambarkan kondisi dan bagian-bagian yang berperan dalam sistem yang dirancang. Perancangan sistem dilakukan dengan menggunakan use-case diagram, activity diagram, sequence diagram dan class diagram.

\section{Use Case Diagram}

Ditunjukkan pada gambar 2. User dapat melakukan Input jumlah runs, Start program dan Exit untuk keluar dari program.

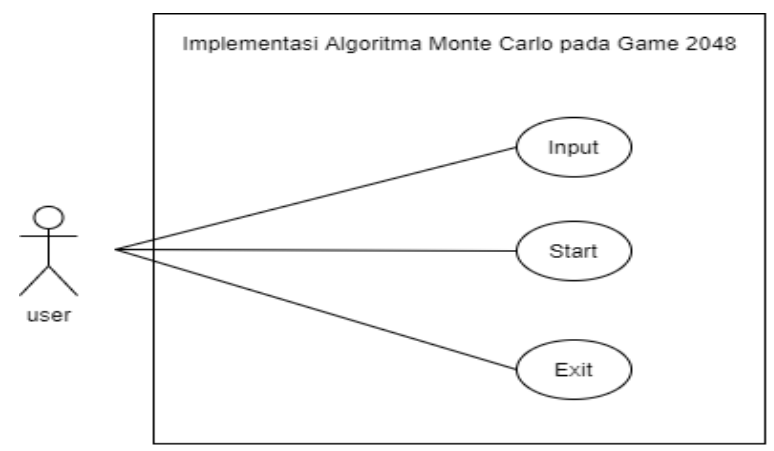

Gambar 2. Use Case Diagram

\section{Activity Diagram}

Ditunjukkan pada gambar 3. User melakukan input setelah itu jika user menekan tombol Start AI maka sistem akan melakukan Generate Move, jika tidak maka menunggu user sampai menekan tombol Start. Setelah itu sistem akan melakukan pengecekan apakah sudah kalah, jika sudah kalah maka sistem akan end, jika belum maka sistem akan melakukan Generate Move.

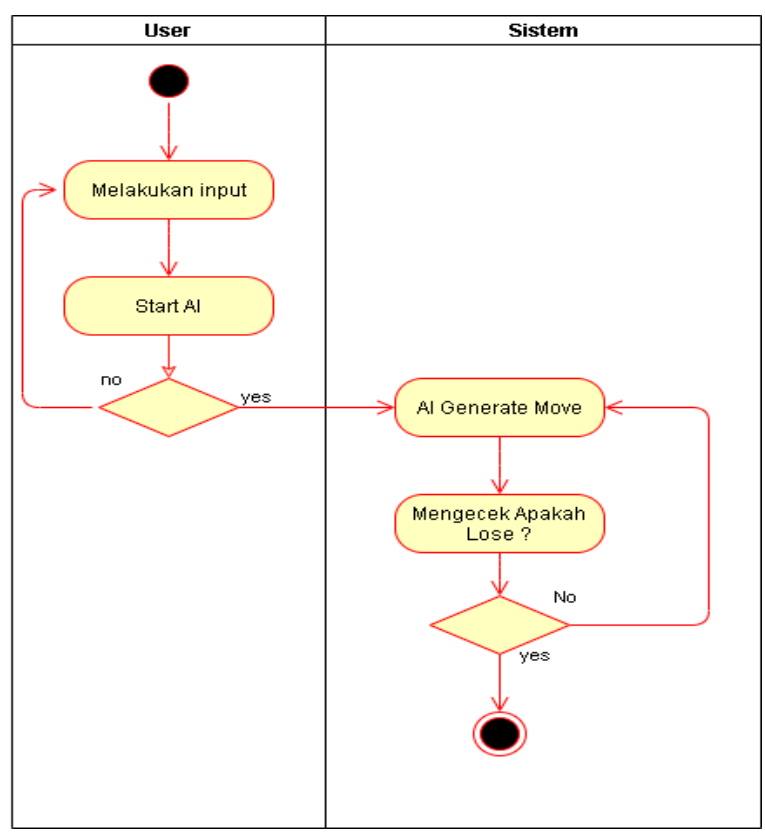

Gambar 3. Activity Diagram 


\section{Sequence Diagram}

Ditunjukkan pada gambar 4. User melakukan inputan nilai runs kepada sistem, setelah itu sistem akan mengirim suatu permintaan kepada algoritma untuk dilakukan proses perhitungan, jika algoritma sudah selesai melakukan perhitungan maka algoritma akan memberi respon balik ke sistem dengan memberikan hasil, dan setelah itu sistem akan melakukan pergerakan secara otomatis sesuai dengan nilai inputan yang diterima oleh user.

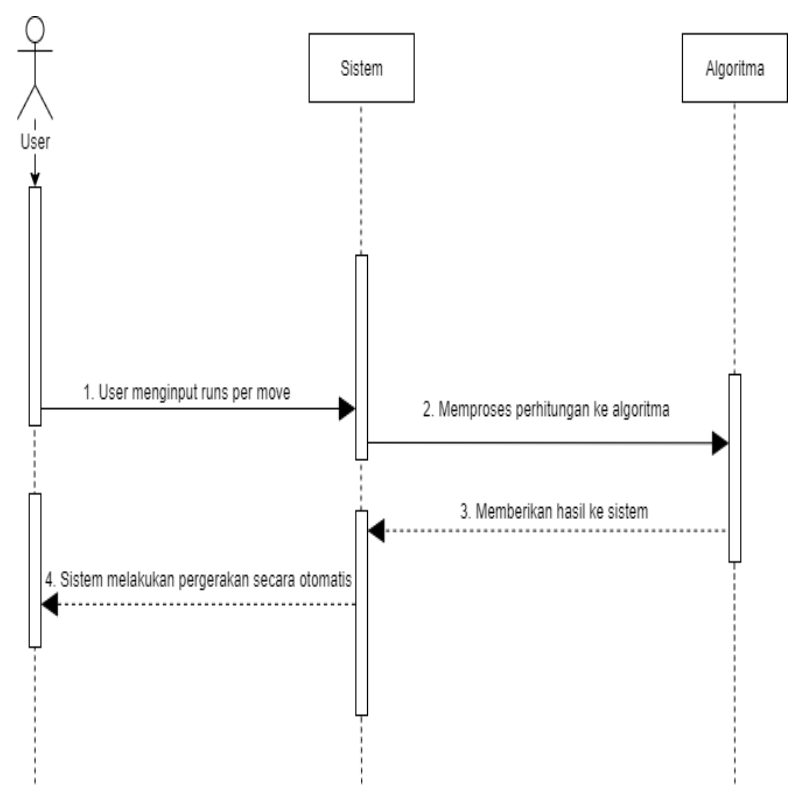

Gambar 4. Sequnce Diagram

\section{Class Diagram}

Pada gambar 5. ditunjukkan bahwa ada kelas AI dimana merupakan kelas untuk melakukan proses Generate Move. Dimana kelas AI memiliki 3 attribute yaitu InputRuns, Status dan Score serta method yaitu generateMove().

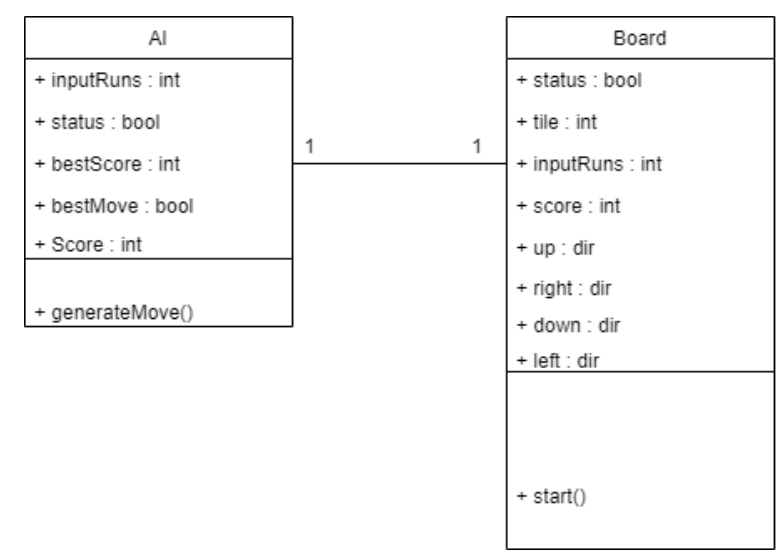

Gambar 5. Class Diagram

Fungsi moveName berguna untuk melakukan inisialisasi move berdasarkan nilai yang telah ditentukan.

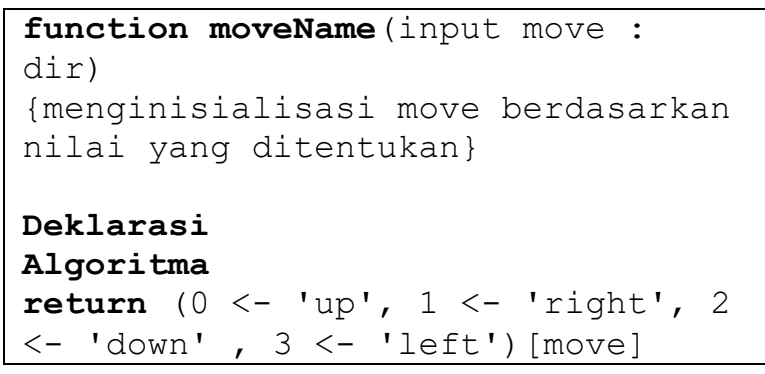

Gambar 6. Fungsi moveName

Fungsi AI_getBest merupakan fungsi untuk memulai perhitungan proses algoritma Monte Carlo dan mendapatkan move terbaik berdasarkan perhitungan yang telah dilakukan.

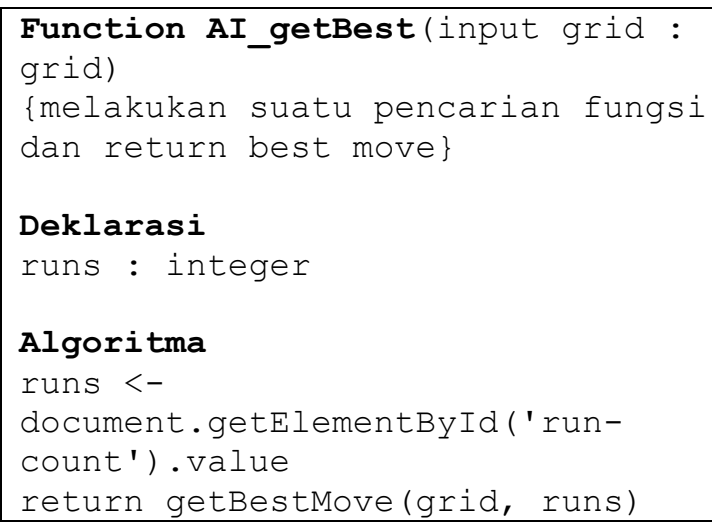

Gambar 7. Fungsi $A I \_g e t B e s t$ 
Fungsi MonteSearch berguna untuk melakukan pencarian mencari bestMove pada tree dan akan terus melakukan looping terhadap seluruh move yang sudah diinisialisasi dan setelah itu menentukan nilai tertinggi yang sudah didapatkan.

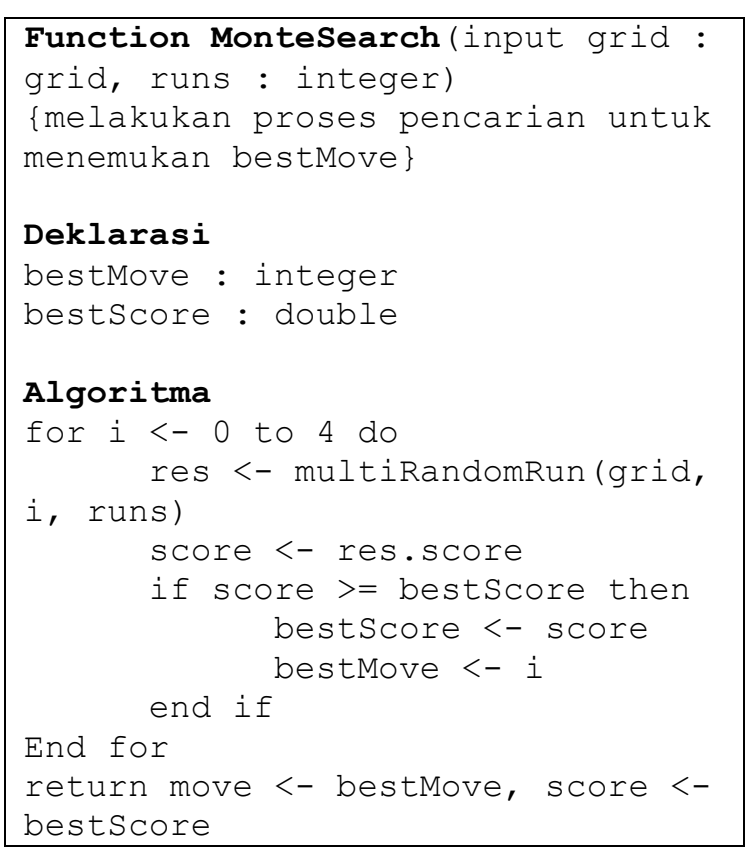

\section{Gambar 8. Fungsi MonteSearch}

Fungsi multiRandomRun berguna untuk melakukan suatu penambahan cabang tree pada algoritma Monte Carlo berdasarkan nilai input yang telah ditentukan oleh user yaitu runs. Dan masing-masing move akan dilakukan looping sebanyak runs.

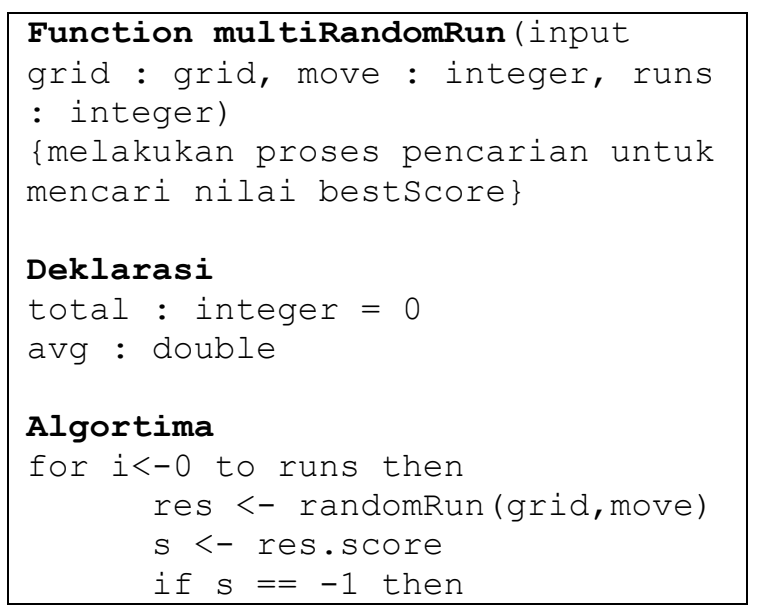

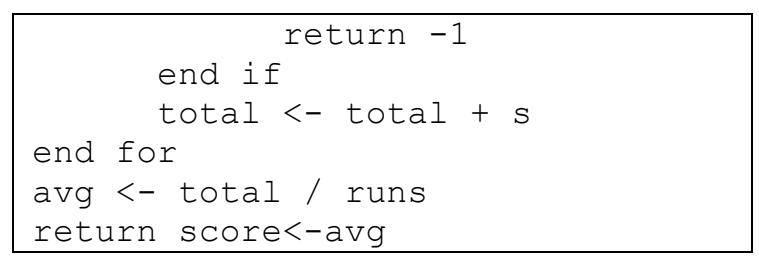

\section{Gambar 9. Fungsi multiRandomRun}

Fungsi randomRun berguna untuk melakukan proses simulasi tree pada algoritma Monte Carlo. Dengan melakukan random move pada move yang sedang dijalankan serta looping pada papan yang telah dilakukan klon sampai tidak dapat melakukan move dan setelah itu akan melakukan return score untuk update nilai bestScore.

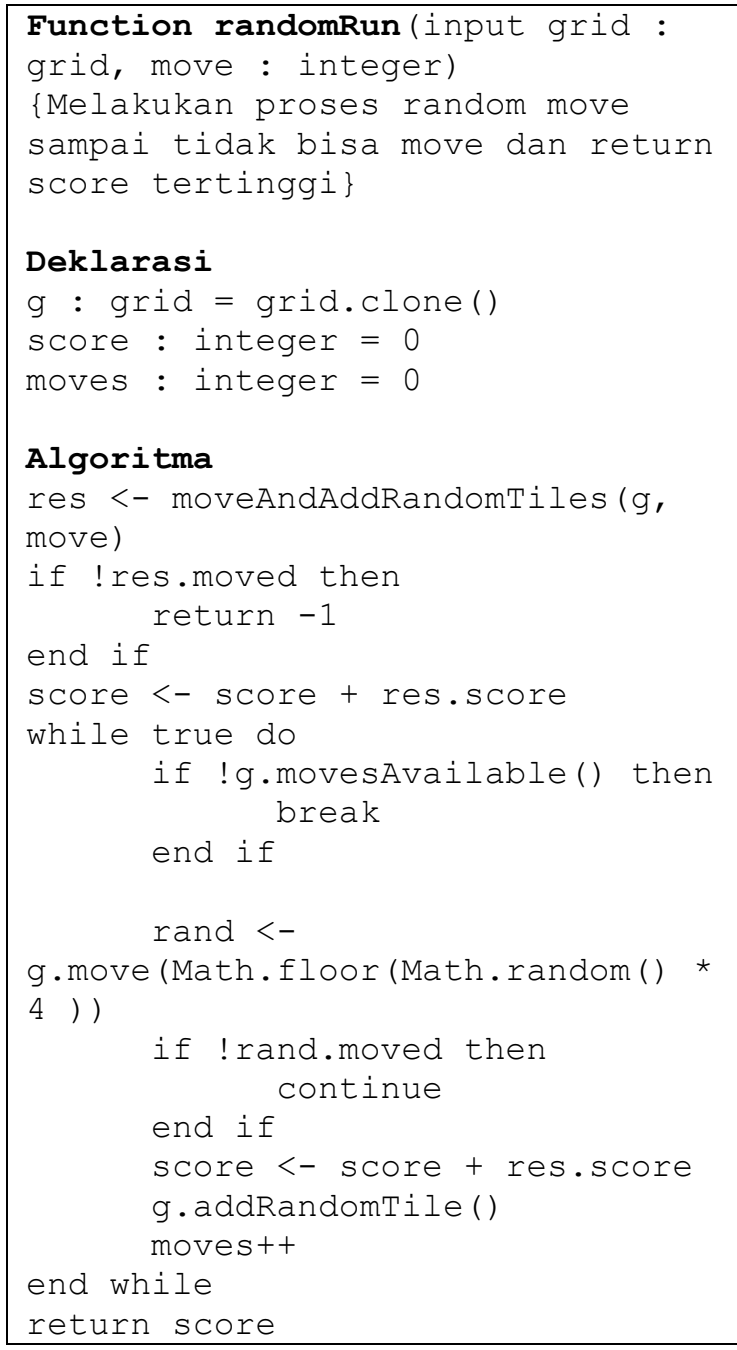

\section{Gambar 10. Fungsi randomRun}


Fungsi yang digunakan untuk melakukan proses move dan menambahkan random tile jika memungkinkan untuk melakukan pergerakan.

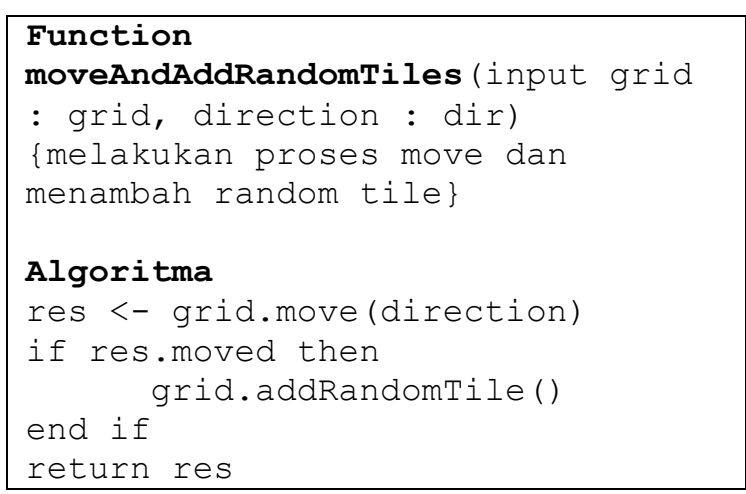

\section{Gambar 11. Fungsi moveAndAdd}

Berikut merupakan penjelasan dari gambar yang ada pada gambar 12 :

1. Score: merupakan tempat dimana skor akan ditampilkan.

2. Run : merupakan tombol yang berfungsi untuk menjalankan program.

3. Input runs per move : merupakan input yang akan diproses oleh algoritma sebagai total pergerakan yang akan dilakukan untuk setiap move.

4. Tile : merupakan tempat berupa kotak berukuran $4 \times 4$ yang berfungsi sebagai tempat untuk menjalankan permainan 2048.

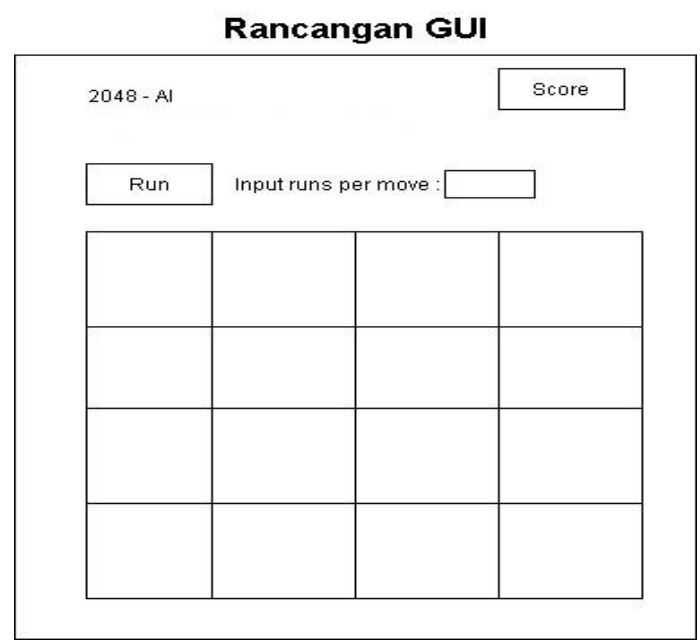

Gambar 12. Tampilan GUI
Pada gambar 13. Merupakan tampilan ketika pertama kali program dijalankan. User hanya perlu melakukan input berupa angka pada bagian sebelah kanan, lalu selanjutnya dapat dengan menekan tombol run. Lalu program akan memproses algoritma monte carlo tree search dan secara otomatis akan melakukan pergerakan sampai button run dihentikan atau permainan berakhir karena tidak dapat melakukan move.

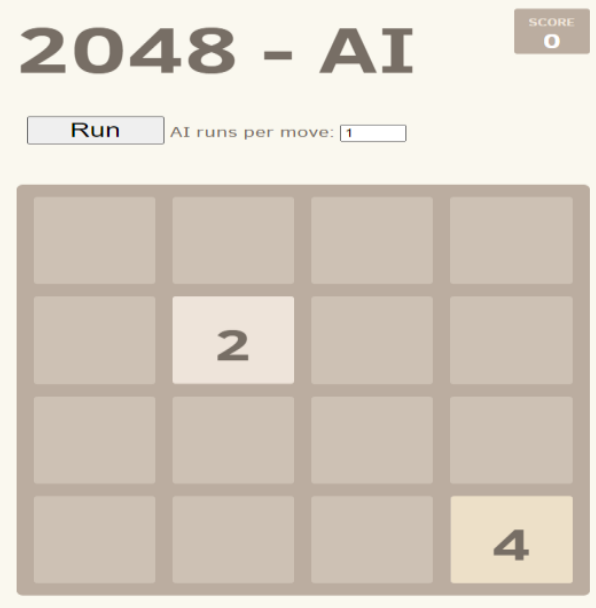

\section{Gambar 13. Tampilan Awal}

Pada gambar 14, merupakan tampilan game over. Jika tidak terdapat gerakan yang dapat dilakukan maka tampilan hanya seperti itu.

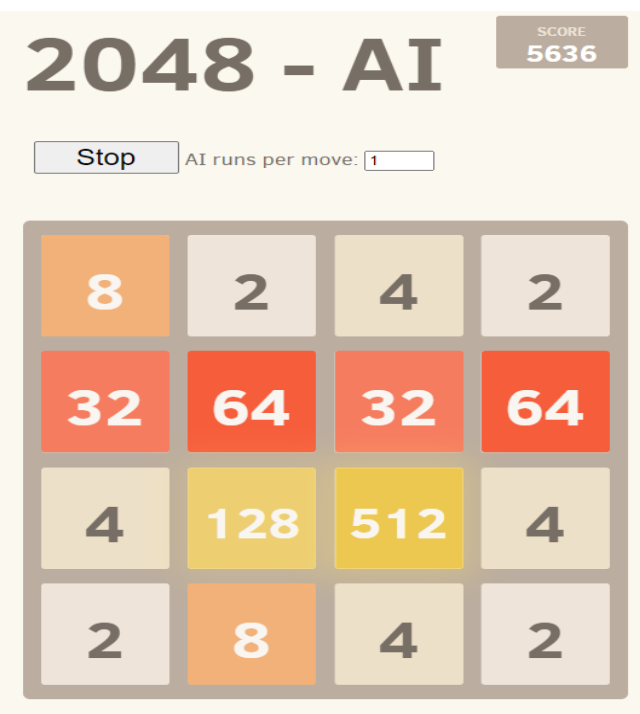

Gambar 14. Tampilan GameOver 
Pengujian dilakukan dengan cara membandingkan hasil dari perbedaan antara inputan nilai runs dengan masing-masing diuji sebanyak 5 kali. Terdapat contoh nilai runs yang akan digunakan sebagai uji coba pada penelitian ini, yaitu :

1. Nilai runs 1

2. Nilai runs 10

3. Nilai runs 100

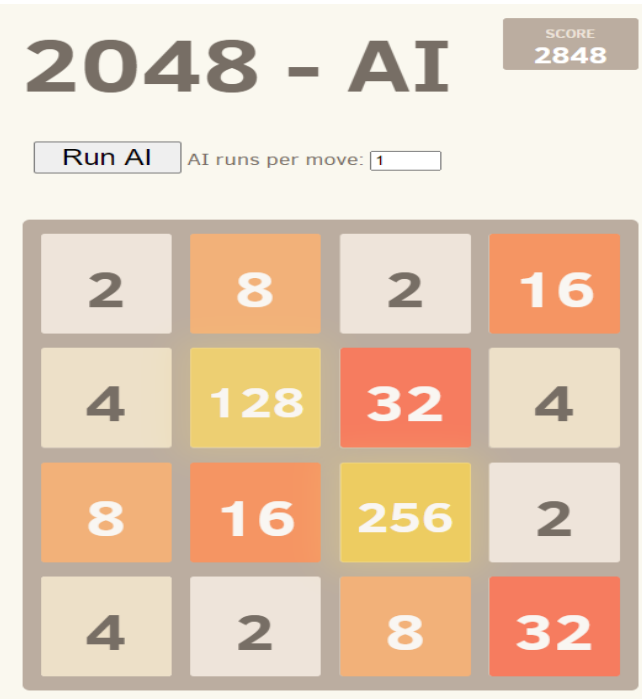

Gambar 15. Percobaan 1

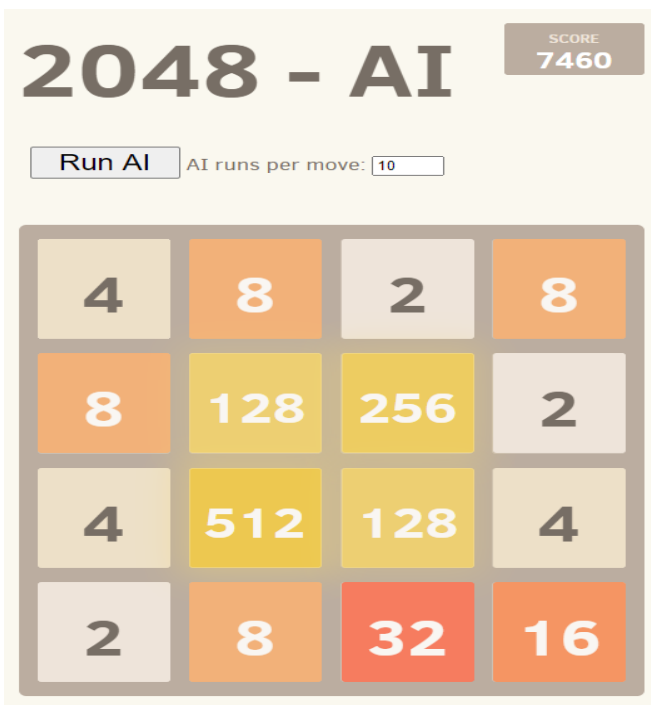

Gambar 16. Percobaan 6

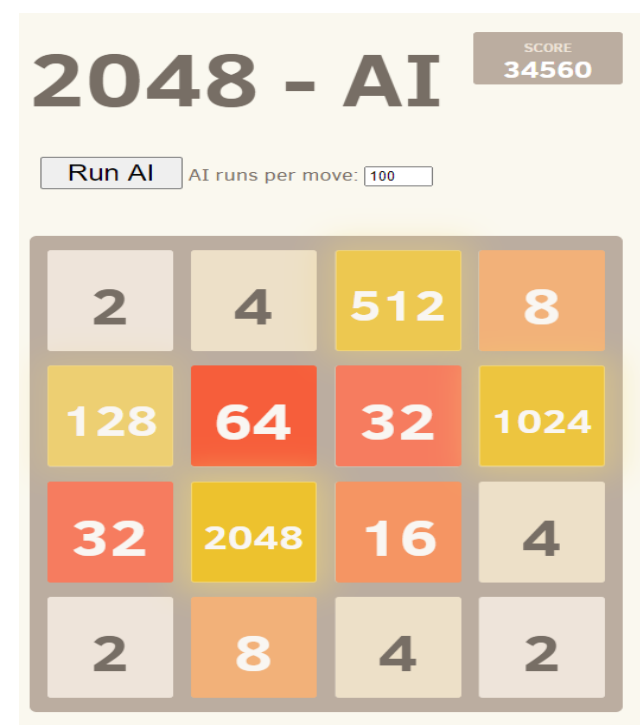

Gambar 17. Percobaan 11

Pada tabel 1. Ditunjukkan bahwa terdapat 4 percobaan dengan nilai runs yang berbeda dan masing-masing percobaan dilakukan selama 5 kali. Didapati bahwa nilai rata-rata tersebut berbeda-beda, Terlihat jelas perbedaan antara masing-masing percobaan yaitu perbedaan score. Dan dapat dikatakan bahwa semakin besar nilai runs maka semakin besar juga nilai score yang bisa didapatkan.

Tabel 1. Analisis Hasil Percobaan

\begin{tabular}{ccccccccc}
\hline No & Nilai & \multicolumn{6}{c}{ Score percobaan } & \multirow{2}{*}{$\begin{array}{c}\text { Average } \\
\text { score }\end{array}$} \\
\cline { 3 - 7 } & Run & $\mathbf{1}$ & $\mathbf{2}$ & $\mathbf{3}$ & $\mathbf{4}$ & $\mathbf{5}$ & \\
\hline 1 & 1 & 2848 & 6252 & 400 & 5012 & 5380 & 3978.4 \\
2 & 10 & 7460 & 13544 & 16824 & 10520 & 15928 & 12855.2 \\
3 & 100 & 34560 & 59720 & 51328 & 35408 & 56500 & 47503.2 \\
\hline
\end{tabular}

\section{KESIMPULAN}

Berdasarkan hasil penelitian yang telah dilakukan, diketahui bahwa algoritma Monte Carlo Tree Search dapat diterapkan pada permainan 2048 Dapat diterapkan dengan cara melakukan pengulangan sebanyak inputan dari 
nilai runs oleh user pada masing-masing move. Setiap move dilakukan pengecekan jika bisa bergerak maka akan melakukan move pada arah tersebut jika tidak maka akan dilewati dan akan mengecek move selanjutnya dan setelahnya akan dilakukan simulasi yaitu move secara acak sampai tidak dapat bergerak, setelah itu akan melakukan return nilai total yang didapat dari hasil simulasi tersebut lalu hasil akan dibandingkan untuk dijadikkan move yang akan menjadi pergerakan selanjutnya.

Cara kerja dari Algoritma Monte Carlo Tree Search pada permainan 2048 adalah dengan memilih move yang telah diinisialisasi dan akan dilakukan penelusuran cabang tree pada masingmasing move tersebut dan akan dilakukan pengecekan jika move tersebut dapat digerakkan. Jika dapat maka akan dilakukan simulasi yaitu melakukan pergerakan move secara random sampai tidak dapat melakukan move lagi sebanyak nilai yang telah diinput oleh user dan setelah itu akan melakukan backpropagation ke cabang teratas dan akan return nilai total dari cabang tersebut. Lalu akan melakukan pengecekan sampai seluruh cabang telah diproses setelah itu baru akan ditentukan move berdasarkan cabang dengan nilai tertinggi.

\section{DAFTAR PUSTAKA}

[1] M. Yulfikar, U. Yudatama, and E. U. Artha, "REDIKSI KETERSEDIAAN STOK KAYU DENGAN METODE BACKPROPOGATION DAN JARINGAN KOHONEN (Studi Kasus Ud. Wahyu Nugroho Grabag Magelang)," J. Komtika, vol. 2, no. 2, pp. 115-124, 2019, doi: 10.31603/komtika.v2i2.2598.
[2] G. R. Meliani and A. Suryadi, "GAME ARTIFICIAL INTELEGENT: RAM CITY TOWER DENGAN ALGORITMA A*," J. PETIK, vol. 3, no. 2, pp. 31-38, May 2018, doi: 10.31980/jpetik.v3i2.148.

[3] B. Y. Geni, J. Santony, and Sumijan, "Prediksi Pendapatan Terbesar pada Penjualan Produk Cat dengan Menggunakan Metode Monte Carlo," J. Inform. Ekon. Bisnis, vol. 1, no. 4, pp. 15-20, Oct. 2019, doi: 10.37034/infeb.v1i4.5.

[4] P. Dong, H. Liu, and L. Xing, "Monte Carlo tree search -based non-coplanar trajectory design for station parameter optimized radiation therapy (SPORT)," Phys. Med. Biol., vol. 63, no. 13, 2018, doi: 10.1088/1361-6560/aaca17.

[5] Y. Amrizal and R. Kurniati, "Game Aritmatika Berbasis Android," INOVTEK Polbeng - Seri Inform., vol. 1, no. 2, p. 100, Nov. 2016, doi: 10.35314/isi.v1i2.121.

[6] N. Kondo and K. Matsuzaki, "Playing game 2048 with deep convolutional neural networks trained by supervised learning," J. Inf. Process., vol. 27, no. Section 6, pp. 340-347, 2019, doi: 10.2197/ipsjjip.27.340.

[7] D. Putra and E. Triastuti, "Application of E-Learning and Artificial Intelligence in Education Systems in Indonesia," Int. J. Comput. Appl., vol. 177, no. 27, pp. 1622, Dec. 2019, doi: 10.5120/ijca2019919739.

[8] D. Silver et al., "Mastering the game of Go with deep neural networks and tree search," Nature, vol. 529, no. 7587, pp. 484-489, 2016, doi: $10.1038 /$ nature 16961.

[9] C. Li, W. Xu, S. Huang, and L. Yang, "A Monte Carlo tree search-based method for online decision making of generator startup sequence considering hot start," Int. J. Electr. Power Energy Syst., vol. 121, no. April, p. 106070, 2020, doi: 10.1016/j.ijepes.2020.106070.

[10] S. Mariko, "Aplikasi website berbasis HTML dan JavaScript untuk menyelesaikan fungsi integral pada mata kuliah kalkulus," J. Inov. Teknol. Pendidik., vol. 6, no. 1, pp. 80-91, 2019, doi: 10.21831/jitp.v6i1.22280. 